\title{
An analysis of verbal fluency task performance profiles in patients with vascular brain pathology
}

\author{
Profilowa analiza wykonania zadań fluencji słownej \\ osób z naczyniopochodną patologią mózgu
}

\author{
1 Department of Clinical Psychology and Neuropsychology, Institute of Psychology, Maria Curie-Sklodowska University, Lublin, Poland \\ 2 Provincial Specialist Hospital, Biała Podlaska, Poland \\ Correspondence: Ewa Małgorzata Szepietowska, Department of Psychology and Neuropsychology, Institute of Psychology, Marie Curie-Sklodowska University, pl. Litewski 5, 20-080 Lublin, Poland, \\ ORCID ID: http://orcid.org/0000-0003-3383-0353, e-mail: ewa.szepietowska@poczta.umcs.lublin.pl
}

\author{
${ }^{1}$ Katedra Psychologii Klinicznej i Neuropsychologii, Instytut Psychologii, Wydział Pedagogiki i Psychologii, Uniwersytet Marii Curie-Skłodowskiej, Lublin, Polska \\ ${ }^{2}$ Wojewódzki Szpital Specialistyczny, Biała Podlaska, Polska \\ Adres do korespondencji: Dr hab. Ewa Małgorzata Szepietowska, prof. UMCS, Katedra Psychologii Klinicznej i Neuropsychologii, Instytut Psychologii, Wydział Pedagogiki i Psychologii, \\ Uniwersytet Marii Curie-Skłodowskiej, ul. Głęboka 45, 20-612 Lublin, ORCID ID: http://orcid.org/0000-0003-3383-0353, e-mail: ewa.szepietowska@poczta.umcs.lublin.pl
}

\begin{abstract}
Aim: Considering the data on the important role of verbal fluency tasks in neuropsychological diagnosis and the models of hemispherically specialised modulation of processes essential for different types of verbal fluency, we made an attempt to identify differences in correct and incorrect performance of 5 verbal fluency tasks between patients with vascular cerebral pathology, including hypertension, and healthy individuals. We also analysed task performance profiles within the groups. Materials and methods: The study included healthy volunteers $(n=36)$, hypertensive individuals $(n=33)$, and patients after left $(n=15)$ or right hemisphere stroke $(n=30)-114$ subjects in total. We used the Frenchay Aphasia Screening Test (FAST) to exclude patients with significant language difficulties/aphasia. We used 5 verbal fluency tasks: semantic (Animals), phonemic ("k"), verb fluency and two emotional tasks: Joy and Fear. We used general linear models for repeated measures for the analysis of correctly and incorrectly performed tasks. Results: The profiles of correct responses for all 5 tasks were similar in all groups, with quantitative intergroup differences. The highest number of correct responses appeared in the semantic, phonemic and verb fluency tasks, whereas the lowest number in the emotional tasks. Hypertensive individuals scored statistically insignificantly lower than healthy individuals, whereas patients after right/left hemisphere stroke scored significantly lower compared to both these groups. Despite a large number of errors, healthy individuals had the highest scores. Patients after right hemisphere stroke showed little differentiation in the number of correct responses in subsequent tasks. There were no intergroup differences in the level of performance of emotional tasks with different valences (positive and negative). Healthy and hypertensive individuals were characterised by a distinct heterogeneity of correct and incorrect responses in various tasks. Patients with brain pathology, regardless of its lateralisation, performed these tasks at a similar level, with left hemisphere damage resulting in the highest number of errors, mainly in semantic and phonemic tasks, and with right hemisphere pathology associated with errors in all types of tasks. The difficulties in patients with left hemisphere damage may result from weaker phonological and lexical processes, including access to semantic features of a word, while the low scores of patients with right hemisphere damage may be a consequence of impaired attention and executive processes. Conclusions: Patients with vascular pathology of the brain hemispheres achieved significantly lower scores in all types of fluency, while hypertensive individuals scored insignificantly lower than healthy subjects. This means that the method can be useful in differentiating between healthy individuals and patients with central nervous system damage, as well as those at risk. Future research should focus on a detailed analysis of the types of errors made by patients with hemispheric damage in various types of verbal fluency tasks. An analysis of the location of the pathology in the anterior-posterior dimension of each hemisphere could reveal specific features of verbal fluency
\end{abstract}

Keywords: verbal fluency, brain damage lateralisation, arterial hypertension

Streszczenie Cel: Uwzględniając dane wskazujące na istotną rolę zadań fluencji słownej w diagnozowaniu neuropsychologicznym oraz modele półkulowo zróżnicowanej regulacji procesów niezbędnych do realizacji różnych typów fluencji słownej, podjęto próbę wykazania istnienia różnic pomiędzy osobami z naczyniową patologią mózgu, w tym z nadciśnieniem tętniczym, i osobami zdrowymi, w zakresie poprawnego i błędnego wykonania 5 zadań fluencji słownej. Analizowano także profile wykonania zadań 
wewnątrz grup. Materiał i metoda: $\mathrm{W}$ badaniach uczestniczyły osoby zdrowe $(n=36)$, z nadciśnieniem tętniczym $(n=33)$ oraz po udarze lewej $(n=15)$ lub prawej $(n=30)$ półkuli mózgu - łącznie 114 osób. Na podstawie wyniku w teście Frenchay Aphasia Screening Test (FAST) z badań wyłączono pacjentów przejawiających cechy znacznych trudności językowych/afazji. Wykorzystano 5 zadań fluencji słownej: semantyczne (Zwierzęta), fonemiczne (głoska „k”), fluencję czasownikową oraz dwa zadania emocjonalne: Radość i Strach. W analizach poprawnych oraz błędnych wykonań wykorzystano ogólne modele liniowe dla pomiarów powtarzanych. Wyniki: Profile poprawnych odpowiedzi w kolejnych 5 zadaniach były podobne we wszystkich grupach, a różnice międzygrupowe miały charakter ilościowy. Najwięcej poprawnych odpowiedzi pojawiło się w zadaniach: semantycznym, fonemicznym i we fluencji czasownikowej, najmniej zaś w zadaniach emocjonalnych. Osoby z nadciśnieniem tętniczym uzyskały wyniki nieistotnie niższe od zdrowych badanych, z kolei pacjenci po udarze prawej i lewej półkuli - istotnie niższe od obydwu tych grup. Osoby zdrowe mimo dużej liczby błędów uzyskały wyniki najwyższe. Pacjenci po udarze prawej półkuli cechowali się małym zróżnicowaniem liczby poprawnych realizacji w kolejnych zadaniach. Zadania emocjonalne o odmiennej walencji (pozytywnej i negatywnej) zostały wykonane na takim samym poziomie przez wszystkie grupy. Grupy osób zdrowych oraz z nadciśnieniem tętniczym cechowała wyraźna heterogeniczność poprawnych i błędnych odpowiedzi w różnych zadaniach. Osoby z patologią mózgu, niezależnie od lateralizacji, wykonywały je na podobnym poziomie, przy czym uszkodzenia lewej półkuli skutkowały największą liczbą błędów przede wszystkim w zadaniu semantycznym i fonemicznym, patologia prawej półkuli zaś - we wszystkich typach zadań. Trudności osób z patologią lewej półkuli mogą wynikać z osłabienia procesów fonologiczno-leksykalnych, w tym dostępu do semantycznych cech słowa, z kolei niskie wyniki pacjentów z uszkodzeniem prawej półkuli mogą być skutkiem zakłóceń procesów uwagowych i wykonawczych. Wnioski: Osoby z naczyniową patologią półkul uzyskały istotnie niższe wyniki we wszystkich typach fluencji, natomiast z nadciśnieniem tętniczym - nieistotnie niższe w porównaniu z osobami zdrowymi. Oznacza to, że metoda może być przydatna w różnicowaniu osób zdrowych i z uszkodzeniem ośrodkowego układu nerwowego, a także osób z grup ryzyka. W kolejnych badaniach uwagę należałoby poświęcić szczegółowej analizie typów błędów popełnianych przez osoby z patologią półkul w różnych typach zadań fluencji słownej. Uwzględnienie lokalizacji patologii w wymiarze obszar przedni - tylny każdej z półkul mogłoby ujawnić specyficzne cechy wykonania fluencji słownej.

Słowa kluczowe: fluencja słowna, lateralizacja patologii mózgu, nadciśnienie tętnicze

\section{INTRODUCTION}

$\mathrm{A}$ person performing verbal fluency tasks is asked to produce words within a specific category (e.g. semantic, phonological, grammatical) within 1 minute. Performance is usually assessed based on correct responses (i.e. in accordance with the instructions) and errors (perseverations, intrusions). Emotional verbal fluency (EVF) is less known. A person performing the task is asked to produce the names of phenomena, persons and situations they associate with certain emotional categories (joy, fear, etc. or pleasant and unpleasant) (Homskaya and Batowa, 1992; Lam and Marquardt, 2020; Sass et al., 2013; Wauters and Marquardt, 2018), or the names of positive and negative emotional states (Abeare et al., 2017).

The use of different versions of verbal fluency tasks in neuropsychological diagnosis has a long tradition (Troyer and Moscovitch, 2006), also in Poland (Jodzio, 2006; Sitek et al., 2014). Despite being brief, they make it possible to assess the efficiency of different cognitive functions (Whiteside et al., 2016): semantic fluency (SF) - semantic memory (Ardila et al., 2006; Shao et al., 2014), phonemic fluency (PF) executive functions - inhibition of semantic strategies and phonetic initiation (Troyer and Moscovitch, 2006). Verb fluency (VF) engages semantic processes and, to a larger extent, executive functions (Paek et al., 2020; Shao et al., 2014; Szepietowska and Gawda, 2014). On the other hand, recalling words from emotional categories requires the involvement of autobiographical memory due to the need for, at least to some extent, adopting a personal perspective

\section{WSTĘP}

$\mathrm{P}$ odczas wykonywania zadań fluencji słownej osoba badana w czasie 1 minuty jest proszona o wymienianie słów zgodnie z wyznaczonymi kryteriami (np. semantycznymi, fonologicznymi, gramatycznymi). Najczęściej za wskaźniki wykonania przyjmuje się liczbę poprawnie (tj. zgodnie z instrukcją) wymienionych słów i liczbę błędów (perseweracji, wtrąceń). Mniej znana jest emocjonalna wersja fluencji słownej (emotional verbal fluency, EVF): zadaniem badanego jest wymienianie nazw zjawisk, osób, sytuacji, które kojarzą mu się z kategoriami emocjonalnymi (radość, strach itp. lub przyjemne i nieprzyjemne) (Homskaya i Batowa, 1992; Lam i Marquardt, 2020; Sass et al., 2013; Wauters i Marquardt, 2018), lub nazw pozytywnych i negatywnych stanów emocjonalnych (Abeare et al., 2017).

Zastosowanie różnych wersji zadań fluencji słownej w diagnozie neuropsychologicznej ma wieloletnią tradycję (Troyer i Moscovitch, 2006), także w Polsce (Jodzio, 2006; Sitek et al., 2014). Mimo krótkiego czasu ich trwania umożliwiają one ocenę sprawności różnych funkcji poznawczych (Whiteside et al., 2016): fluencja semantyczna (semantic fluency, SF) - pamięci semantycznej (Ardila et al., 2006; Shao et al., 2014), fonemiczna zaś (phonemic fluency, PF) - funkcji wykonawczych - hamowania strategii semantycznych i inicjowania fonetycznych (Troyer i Moscovitch, 2006). Wymienianie czasowników (verb fluency, VF) angażuje procesy semantyczne, ale w większym stopniu funkcje wykonawcze (Paek et al., 2020; Shao et al., 2014; Szepietowska i Gawda, 2014). Z kolei przypominanie sobie słów z kategorii emocjonalnych wymaga udziału pamięci 
as well as semantic memory and executive functions (Abbassi et al., 2011).

The brain area involved in concept recollection is an extensive network of cortical and subcortical structures of both hemispheres and the cerebellum (Molinari and Leggio, 2016). A large body of evidence indicates that the distinctiveness of the neural basis of the different types of fluency is only partial. Despite evidence supporting the significant role of the left hemisphere (LH), research indicates that the right hemisphere $(\mathrm{RH})$ is also involved in this process. The temporal lobe of the left hemisphere (Birn et al., 2010; Klaus and Hartwigsen, 2019; Stuss et al., 1998), but also the inferior frontal gyrus of the right hemisphere (Biesbroek et al., 2016) are activated during semantic verbal fluency tasks. Activation of the prefrontal cortex of the left hemisphere, as well as the insula, the frontal lobe and the caudate nucleus in the right hemisphere is observed during phonemic tasks (Sanjuán et al., 2010; Wagner et al., 2014). Verb production activates the fronto-striatal loop and the parietotemporal regions of both hemispheres (Sanjuán et al., 2010; Szepietowska and Gawda, 2014). Both hemispheres are also involved in performing EVF tasks (Abbassi et al., 2011; Gawda et al., 2017; Riès et al., 2016). The role of the $\mathrm{RH}$ is to activate significant attentional resources, the control of attention and working memory (Goldberg and Costa, 1981), as well as to help recall emotionally charged autobiographical memories (Cabeza and St Jacques, 2007). The $\mathrm{LH}$, on the other hand, is involved in extracting the emotional words and words that commonly have an emotional meaning by activating well-established semantic knowledge that does not require personal emotional experience (Abbassi et al., 2011).

Interpretation of verbal fluency performance profile plays an important role in neuropsychological diagnosis. The specific features of task performance may be shaped, on the one hand, by the specificity (e.g. localisation) of brain damage in various central nervous system (CNS) diseases and, on the other hand, by partially separate brain mechanisms activated when performing various tasks. For example, patients with Alzheimer's disease, vascular dementia and healthy individuals (Zhao et al., 2013) or patients with Parkinson's and Huntington's diseases (Sitek et al., 2014) had different patterns of performing various types of fluency tasks. Heterogeneity of results, which results from different levels of task difficulty, is also observed in healthy individuals, who usually perform better in SF (Ardila et al., 2006) than PF and VF (Tallberg et al., 2008), and generate the lowest number of items in EVF tasks (Gawda et al., 2017). Compared to individuals without vascular diseases, patients with controlled hypertension (HT), which is a risk factor for vascular dementia, score insignificantly lower in SF and PF (Morelli et al., 2017); however, longitudinal studies show a decrease in performance with the duration of the disease (Jimenéz et al., 2018). The performance profiles of patients with vascular CNS pathologies may in turn vary depending on stroke lateralisation (Schmidt et al., 2019). Greater autobiograficznej ze względu na konieczność, przynajmniej w jakimś stopniu, przyjęcia osobistej perspektywy podczas wymieniania pojęć mających pozytywną lub negatywną konotację, a także pamięci semantycznej i funkcji wykonawczych (Abbassi et al., 2011).

Mózgowe podłoże przypominania sobie pojęć obejmuje rozległą sieć obszarów korowych i podkorowych obu półkul oraz móżdżek (Molinari i Leggio, 2016). Wiele danych przemawia za jedynie częściową odrębnością neuronalnego podłoża realizacji różnych typów fluencji. Mimo dowodów na istotny udział lewej półkuli (LP) badania wskazują na zaangażowanie także prawej półkuli (PP). W wykonaniu wersji semantycznych uczestniczy okolica skroniowa LP (Birn et al., 2010; Klaus i Hartwigsen, 2019; Stuss et al., 1998), ale też dolny zakręt czołowy PP (Biesbroek et al., 2016). Realizacji zadań fonemicznych towarzyszy aktywacja kory przedczołowej LP oraz wyspy, płata czołowego i jądra ogoniastego w PP (Sanjuán et al., 2010; Wagner et al., 2014). Wymienianie czasowników angażuje pętlę czołowo-prążkowiową oraz obszary ciemieniowo-skroniowe obu półkul (Sanjuán et al., 2010; Szepietowska i Gawda, 2014). W realizację EVF również zaangażowane są obydwie półkule (Abbassi et al., 2011; Gawda et al., 2017; Riès et al., 2016). Rolą PP jest tu uruchomienie znacznych zasobów uwagowych, kontroli uwagi i pamięci operacyjnej (Goldberg i Costa, 1981) oraz udział w przypominaniu danych autobiograficznych o emocjonalnym charakterze (Cabeza i St Jacques, 2007). Z kolei LP uczestniczy w wydobywaniu nazw emocji i słów powszechnie mających znaczenie emocjonalne wskutek uruchomienia dobrze utrwalonej wiedzy semantycznej, niewymagającej jednak osobistego emocjonalnego doświadczenia (Abbassi et al., 2011).

Analiza profilu wyników w zadaniach fluencji zajmuje istotne miejsce w diagnozowaniu neuropsychologicznym. Z jednej strony specyfika (np. lokalizacja) patologii mózgowej w różnych schorzeniach ośrodkowego układu nerwowego (OUN), a z drugiej częściowo odrębne mózgowe mechanizmy uruchamiane w toku wykonywania różnych zadań mogą kształtować charakterystyczne cechy ich wykonań. Przykładowo, odmienne wzorce realizacji różnych typów zadań fluencji cechowały pacjentów z chorobą Alzheimera, osoby z otępieniem naczyniowym i zdrowe (Zhao et al., 2013) czy też osoby z chorobą Parkinsona i Huntingtona (Sitek et al., 2014). Heterogeniczność wyników, ze względu na różne poziomy trudności zadań, charakteryzuje także osoby zdrowe: zwykle lepiej wykonują one SF (Ardila et al., 2006) niż PF i VF (Tallberg et al., 2008), a najmniej słów pojawia się w EVF (Gawda et al., 2017). $\mathrm{W}$ porównaniu z osobami bez obciążeń naczyniowych pacjenci z kontrolowanym nadciśnieniem tętniczym (NT), będącym czynnikiem ryzyka otępienia naczyniowego, uzyskują nieistotnie niższe wyniki w SF oraz PF (Morelli et al., 2017), niemniej badania podłużne wykazują ich spadek wraz z czasem trwania choroby (Jimenéz et al., 2018). Profile wyników osób z naczyniową patologią OUN mogą być z kolei zróżnicowane zależnie od lateralizacji ogniska udarowego (Schmidt et al., 2019). U osób z naczyniowym uszkodzeniem - patologią 
deficits in SF vs. PF (Kahlaoui et al., 2008) performance and a tendency to produce words unrelated to a given category (Le Blanc and Joanette, 1996) were observed in patients with vascular damage (RH pathology - RHD). Patients with left hemisphere damage (LHD) presented mainly with deficits in PF, whereas difficulties in performing SF tasks usually depend on the severity of aphasia (Bose et al., 2017; Roberts and Le Dorze, 1994). However, not all studies reported similar data (Jodzio, 2006).

There are few reports on the performance of patients with LHD and RHD in EVF tasks. Although the right hemisphere has been shown to be more engaged in processing emotional, especially negatively charged, stimuli (Borod et al., 1998; Gainotti, 2014), other data suggest that the LH is more involved in the processing of emotional verbal stimuli (Martin and Altarriba, 2017). While the emotional context makes it easier for patients with LHD to accomplish their tasks (Ramsberger, 1996), it presents an obstacle for those with RHD (Bloom et al., 1990; Borod et al., 1992). Comparisons of the ability to process negative and positive stimuli showed a "positivity" effect in the RHD group: patients recalled few unpleasant facts from their lives and rated them as less intense than those with LHD and healthy individuals (Buchanan, 2007). However, some studies found no intergroup differences in the number of recalled emotional words (Beraha et al., 2012; Bloom et al., 1990), while other studies have found these differences only in patients with lateral frontal lobe damage (Homskaya and Batowa, 1992).

The concept of hemispheric specialisation for motivation is another context for the analyses of differences in fluency task performance between LHD and RHD patients. The LH is associated with behavioural activation system (BAS), whereas the RH is associated with behavioural inhibition systems (BIS) and responsible for arousing attention to negative stimuli and for experiencing them (Shinagawa et al., 2015). In healthy individuals, a relationship was demonstrated between higher activation of BAS, LH activity and more efficient positive information processing, while higher activation of BIS was accompanied by RH activation and more efficient negative information processing (Cohen and Shaver, 2004). LHD inhibits this activity, making it difficult to extract words (Sutton and Davidson, 1997), while RHD impairs executive functions, resulting in a tendency to go beyond the imposed category in fluency (Knutson et al., 2015).

Models indicating hemispheric specialisation in the regulation of emotional and motivational processes, autobiographical memory, recalling emotional words or the organisation of semantic knowledge allow for conclusions about the differences in the profiles of verbal fluen$c y$ in the groups of patients with vascular brain pathology. Some studies in patients with hemispheric damage and healthy individuals showed both intragroup (different levels of SF, PF, VF and EVF performance) and intergroup differences in the number of correct responses; however, there
PP (PPP) odnotowano większe deficyty w realizacji SF niż w PF (Kahlaoui et al., 2008) oraz tendencję do podawania słów niepowiązanych z kategorią (Le Blanc i Joanette, 1996). U pacjentów z uszkodzeniem - patologią LP (PLP) obserwowano $\mathrm{z}$ kolei przewagę deficytów $\mathrm{w} \mathrm{PF}$, a trudności w realizacji SF są zwykle powiązane z głębokością afazji (Bose et al., 2017; Roberts i Le Dorze, 1994). Jednak część badań nie dostarczyła podobnych danych (Jodzio, 2006).

Niewiele doniesień dotyczy realizacji EVF przez osoby z PLP i PPP. Chociaż wykazywano przewagę PP w przetwarzaniu bodźców emocjonalnych, szczególnie negatywnych (Borod et al., 1998; Gainotti, 2014), to inne dane sugerują przewagę LP w przetwarzaniu bodźców werbalnych o charakterze emocjonalnym (Martin i Altarriba, 2017). Emocjonalny kontekst ułatwia osobom z PLP realizację zadań (Ramsberger, 1996), jest natomiast utrudnieniem dla grup z PPP (Bloom et al., 1990; Borod et al., 1992). Porównania zdolności do przetwarzania bodźców negatywnych i pozytywnych wykazały w grupie z PPP efekt ,pozytywności”: pacjenci przypominali sobie niewiele nieprzyjemnych faktów ze swojego życia i oceniali je jako mniej intensywne niż osoby z PLP oraz zdrowe (Buchanan, 2007). Jednak niektóre badania nie wykazały różnic międzygrupowych w zakresie liczby przypominanych słów emocjonalnych (Beraha et al., 2012; Bloom et al., 1990), inne zaś wykazały te różnice jedynie w odniesieniu do chorych ze stronnymi uszkodzeniami płatów czołowych (Homskaya i Batowa, 1992).

Innym kontekstem analiz różnic w wykonaniu zadań fluencji między osobami z PLP i PPP jest koncepcja półkulowego zróżnicowania regulacji procesów motywacyjnych. LP uczestniczy w aktywacji zachowania (behavioural activation system, BAS), PP natomiast odpowiada za hamowanie zachowania (behavioural inhibition systems, BIS), za wzbudzanie uwagi wobec bodźców negatywnych oraz ich doświadczanie (Shinagawa et al., 2015). U zdrowych osób wykazano związek pomiędzy nasileniem cechy BAS, aktywnością LP i lepszą sprawnością przetwarzania informacji pozytywnych, większemu nasileniu cechy BIS towarzyszyły zaś aktywacja PP i lepsza sprawność w przetwarzaniu informacji negatywnych (Cohen i Shaver, 2004). PLP hamuje aktywność, utrudniając wydobywanie słów (Sutton i Davidson, 1997), a PPP negatywnie wpływa na funkcje wykonawcze, skutkując tendencją do wykraczania poza narzuconą kategorię we fluencji (Knutson et al., 2015).

Modele wskazujące na zróżnicowany udział półkul mózgu w regulacji procesów emocjonalnych, motywacyjnych, pamięci autobiograficznej, przypominania słów emocjonalnych czy organizacji wiedzy semantycznej pozwalają wnioskować o odmiennościach profili wykonania fluencji słownej w grupach osób z naczyniową patologią mózgu. Część badań osób z patologią półkul i zdrowych wykazała różnice zarówno wewnątrzgrupowe (różny poziom wykonania SF, PF, VF i EVF), jak i międzygrupowe w zakresie liczby poprawnych odpowiedzi, ale są też dane wskazujące, że lateralizacja i lokalizacja patologii nie różnicują wyników osób z patologią naczyniową (Babulal, 2016; Salas 
and localisation-related differences in the performance of patients with vascular pathology (Babulal, 2016; Salas Riquelme et al., 2015). On the other hand, recalling words from different categories involves both hemispheres and depends on many other variables (e.g. age), which may explain the heterogeneity of the results. Based on the literature data, we assumed inter- and intragroup differences in the level of task performance. In particular, we expected different patterns of task performance in patients with RHD vs. LHD, as well as between healthy and HT individuals.

\section{MATERIALS AND METHODS}

A total 114 adults, including healthy, previously untreated individuals (control group, C), as well as subjects with HT, RHD and LHD, participated in the study. Inclusion criteria were as follows: computed tomography (CT) or magnetic resonance imaging (MRI) confirmed stroke in the RH or LH, somatic and cognitive status enabling participation in the study and task performance, and patient's consent to use their results in the research. Individuals with multiple or diffuse vascular pathology within each or both hemispheres, patients with hemispheric pathology other than vascular, overall condition or cognitive deficits preventing task performance (e.g. language disorders/aphasia, consciousness and behavioural disorders) and those who did not consent to participate in study were excluded. We used the Frenchay Aphasia Screening Test (FAST) in the Polish version (Bitniok, 1998) to exclude language disorders in subjects after stroke. FAST is used to assess 4 aspects of language skills: comprehension, verbal expression, reading and writing. It takes about 10 minutes to complete the test. The maximum score is 30 . A score $<27$ in a person $\leq 60$ years of age and $<25$ in a person $>61$ years of age indicates aphasia/language disorders. Following this interpretation, persons with a lower score were not included in the study. Healthy participants were enrolled as volunteers. Individuals with HT were recruited among patients visiting the hospital outpatient neuropsychology clinic. Patients after stroke were tested the day before hospital discharge. The participants' data are presented in Tab. 1.

The group with LHD included 15 patients with different localisation of pathology, whereas the group with RHD included 30 patients, also with different localisation of stroke. There were 36 controls and $33 \mathrm{HT}$ subjects. The groups did not differ significantly in terms of age $(F=2.09, p=0.11)$. The actual part of the research involved 5 verbal fluency tasks: SF (names of animals), PF (k-words), VF [generation of words (verbs) that answer a question: what does a man do?]. Before completing each task, the participant was instructed to avoid word inflection (inflected forms were considered errors). Apart from the Animal task, proper names were accepted. Emotional tasks (EVF) required the participants to produce words relating to Joy, and then Fear. Only single words (verbs, nouns, adjectives, proper names) were accepted (sentences were not accepted). Each time, the

\begin{tabular}{|c|c|c|}
\hline $\begin{array}{l}\text { Variables } \\
\text { Zmienne }\end{array}$ & $n$ & $\%$ \\
\hline $\begin{array}{l}\text { Gender: } \\
\text { Płeć: } \\
\text { - males } \\
\quad \text { męska } \\
\text { - females } \\
\quad \text { żeńska }\end{array}$ & $\begin{array}{l}52 \\
62\end{array}$ & $\begin{array}{l}45.6 \\
54.4\end{array}$ \\
\hline $\begin{array}{l}\text { Dwelling place: } \\
\text { Miejsce zamieszkania: } \\
\text { - rural area } \\
\text { wieś } \\
\text { - small town } \\
\text { małe miasto } \\
\text { - voivodeship city } \\
\text { miasto wojewódzkie }\end{array}$ & $\begin{array}{l}44 \\
39 \\
31\end{array}$ & $\begin{array}{l}38.6 \\
34.2 \\
27.2\end{array}$ \\
\hline $\begin{array}{l}\text { Formal education: } \\
\text { Wykształcenie: } \\
\text { - primary } \\
\text { podstawowe } \\
\text { - secondary } \\
\text { średnie } \\
\text { - higher } \\
\text { wyższe } \\
\end{array}$ & $\begin{array}{l}21 \\
53 \\
40\end{array}$ & $\begin{array}{l}18.4 \\
46.5 \\
35.1\end{array}$ \\
\hline $\begin{array}{l}\text { Group: } \\
\text { Grupa: } \\
\text { - stroke } \\
\text { udar } \\
\text { - HT } \\
\text { NT } \\
\text { - C } \\
\text { K }\end{array}$ & $\begin{array}{l}45 \\
33 \\
36\end{array}$ & $\begin{array}{l}36.3 \\
26.6 \\
37.1\end{array}$ \\
\hline $\begin{array}{l}\text { Age } \\
\text { Wiek }\end{array}$ & $M(S D)$ & $\begin{array}{l}\text { Range } \\
\text { Zakres }\end{array}$ \\
\hline $\begin{array}{l}\operatorname{LHD}(n=15) \\
P L P(n=15)\end{array}$ & $\begin{array}{c}54.73 \\
(12.63)\end{array}$ & $34-79$ \\
\hline $\begin{array}{l}\text { RHD }(n=30) \\
P P P(n=30)\end{array}$ & $\begin{array}{c}60.37 \\
(12.52) \\
\end{array}$ & $28-74$ \\
\hline $\begin{array}{l}C(n=36) \\
K(n=36)\end{array}$ & $\begin{array}{l}54.89 \\
(6.46) \\
\end{array}$ & $46-72$ \\
\hline $\begin{array}{l}\mathrm{HT}(n=33) \\
N T(\mathrm{n}=33)\end{array}$ & $\begin{array}{l}55.82 \\
(8.57)\end{array}$ & $41-78$ \\
\hline \multicolumn{3}{|c|}{$\begin{array}{l}\text { C - controls; } \boldsymbol{M} \text { - mean; HT - hypertension group; } \mathbf{L H D} \text { - left hemisphere } \\
\text { damage; } \mathbf{R H D} \text { - right hemisphere damage; } \mathbf{S D} \text { - standard deviation. } \\
\boldsymbol{K} \text { - grupa kontrolna; } \mathbf{M} \text { - mean, średnia; } \boldsymbol{N T} \text { - grupa z nadciśnieniem tętniczym } \\
\mathbf{P L P} \text { - grupa z patologiq lewej półkuli; } \boldsymbol{P P P} \text { - grupa z patologia prawej półkuli, } \\
\text { SD - standard deviation, odchylenie standardowe. }\end{array}$} \\
\hline
\end{tabular}

Tab. 1. Characteristics of study participants

Tab. 1. Charakterystyka uczestników

Riquelme et al., 2015). Z drugiej jednak strony przypominanie słów $\mathrm{z}$ różnych kategorii angażuje obie półkule mózgu $\mathrm{i}$ jest powiązane $\mathrm{z}$ wieloma innymi zmiennymi (np. wiekiem), co może wyjaśniać heterogeniczność wyników. Na podstawie danych omówionych w piśmiennictwie autorki przewidywały międzygrupowe i wewnątrzgrupowe różnice w poziomie wykonania zadań. Spodziewały się szczególnie innych wzorców wykonywania zadań przez osoby z PPP i PLP, ale także różnic pomiędzy osobami zdrowymi i tymi z NT.

\section{MATERIAt I METODY}

W badaniach uczestniczyły dorosłe osoby, w tym: zdrowe, dotychczas się nieleczące (grupa kontrolna - K), 
participants were asked to generate as many words as possible. The time limit for each task was 1 minute. Performance was assessed based on the number of correct (i.e. consistent with the criterion) words and the number of errors in the form of repetitions, words not related to the category, inflected words or sentences.

\section{RESULTS}

The scores obtained by study participants are shown in Tab. 2. Figs. 1 and 2 illustrate correct and incorrect performance profiles, respectively. Tab. 3 shows the results of two general linear models for repeated measurements. We conducted an analysis for 4 groups $\times 5$ fluency tasks (correct answers), taking into account the main effects and interactions, and an analysis of incorrect responses. We used IBM's SPSS v. 26.

A significant main effect of the group variable was noted for the number of correct responses. Belonging to a group had $40 \%$ impact on correct task performance. The lowest and not significantly different mean numbers of all correct responses were obtained in the groups with LHD and RHD $(p=1.0)$. Healthy individuals had the highest mean score, with significant difference compared to RHD $(p=0.001)$ and LHD ( $p=0.001)$ groups, and with no difference compared to the osoby obciążone NT, osoby z PPP i PLP - łącznie 114 osób. Kryteriami włączenia pacjentów do badań były: potwierdzona obrazem tomografii komputerowej lub rezonansu magnetycznego obecność ogniska udarowego w PP lub LP mózgu, stan somatyczny i poznawczy umożliwiający uczestniczenie w badaniu i wykonanie zadań, zgoda chorego na wykorzystanie wyników w badaniach naukowych. Nie włączono osób z licznymi lub rozlanymi ogniskami naczyniopochodnymi w obrębie każdej lub obu półkul, inną niż naczyniowa patologią półkul, ogólnym stanem czy deficytami poznawczymi uniemożliwiającymi wykonanie zadań (np. z zaburzeniami językowymi/afazją, zaburzeniami świadomości i zachowania) oraz niewyrażających zgody na udział w badaniu. W badaniach osób po udarach, w celu wykluczenia obecności zaburzeń językowych, wykorzystano Frenchay Aphasia Screening Test (FAST) w polskiej wersji (Bitniok, 1998). FAST pozwala ocenić 4 aspekty sprawności językowej: rozumienie, ekspresję werbalną, czytanie i pisanie. Jego wykonanie zajmuje około 10 minut. Możliwe jest uzyskanie 30 punktów. O obecności afazji/zaburzeń językowych świadczy wynik poniżej 27 pkt dla osób do 60. roku życia oraz poniżej 25 pkt dla osób powyżej 61. roku życia. Zgodnie z tą regułą do badań nie włączano osób, które otrzymały niższy wynik. Osoby zdrowe były ochotnikami, osoby z NT rekrutowano spośród pacjentów przyszpitalnej

\begin{tabular}{|c|c|c|c|c|}
\hline $\begin{array}{l}\text { Tasks } \\
\text { Zadania }\end{array}$ & $\begin{array}{c}\text { RHD } \\
P P P \\
M(S D) \\
n=30\end{array}$ & $\begin{array}{c}\text { LHD } \\
P L P \\
M(S D) \\
n=15\end{array}$ & $\begin{array}{c}\text { HT } \\
N T \\
M(S D) \\
n=33\end{array}$ & $\begin{array}{c}C \\
K \\
M(S D) \\
n=36\end{array}$ \\
\hline $\begin{array}{l}\text { Animals (correct) } \\
\text { Zwierzęta (poprawne) }\end{array}$ & $12.43(5.55)$ & $11.20(7.11)$ & $21.64(5.87)$ & $22.75(6.069)$ \\
\hline $\begin{array}{l}\text { Animals (errors) } \\
\text { Zwierzęta (błędy) }\end{array}$ & $0.23(0.93)$ & $0.93(0.96)$ & $0.24(0.61)$ & $0.56(0.81)$ \\
\hline $\begin{array}{l}\text { Verbs (correct) } \\
\text { Czasowniki (poprawne) } \\
\end{array}$ & $11.13(6.49)$ & $9.67(9.33)$ & $18.06(5.06)$ & $18.92(4.77)$ \\
\hline $\begin{array}{l}\text { Verbs (errors) } \\
\text { Czasowniki (błędy) }\end{array}$ & $0.03(0.18)$ & $0.33(0.62)$ & $0.39(0.66)$ & $0.56(0.97)$ \\
\hline $\begin{array}{l}\text { Joy (correct) } \\
\text { Radość (poprawne) }\end{array}$ & $5.30(4.08)$ & $5.73(9.17)$ & $10.33(4.56)$ & $11.56(5.04)$ \\
\hline $\begin{array}{l}\text { Joy (errors) } \\
\text { Radość (błędy) }\end{array}$ & $0.03(0.18)$ & 0 & 0 & $0.22(0.54)$ \\
\hline $\begin{array}{l}\text { Fear (correct) } \\
\text { Strach (poprawne) }\end{array}$ & $5.00(3.67)$ & $3.87(4.14)$ & $9.12(5.00)$ & $10.31(4.23)$ \\
\hline $\begin{array}{l}\text { Fear (errors) } \\
\text { Strach (błędy) }\end{array}$ & $0.10(0.55)$ & $0.07(0.26)$ & $0.21(0.54)$ & $0.17(0.69)$ \\
\hline $\begin{array}{l}\text { Phonemic (correct) } \\
\text { Fonemiczne (poprawne) }\end{array}$ & $10.20(4.73)$ & $8.07(4.97)$ & $17.06(4.64)$ & $18.50(5.57)$ \\
\hline $\begin{array}{l}\text { Phonemic (errors) } \\
\text { Fonemiczne (błędy) }\end{array}$ & 0 & $0.47(0.91)$ & $0.09(0.29)$ & $0.17(0.38)$ \\
\hline $\begin{array}{l}\text { Correct responses - mean }(M) \\
\text { Srednia poprawnych odpowiedzi (M) }\end{array}$ & 8.81 & 7.07 & 15.24 & 16.41 \\
\hline $\begin{array}{l}\text { Errors - mean }(M) \\
\text { Średnia błędów }(M)\end{array}$ & 0.08 & 0.36 & 0.19 & 0.33 \\
\hline
\end{tabular}

Tab. 2. Performance of verbal fluency tasks: correct vs. incorrect responses

Tab. 2. Wykonanie zadań fluencji słownej: odpowiedzi poprawne i błędne 


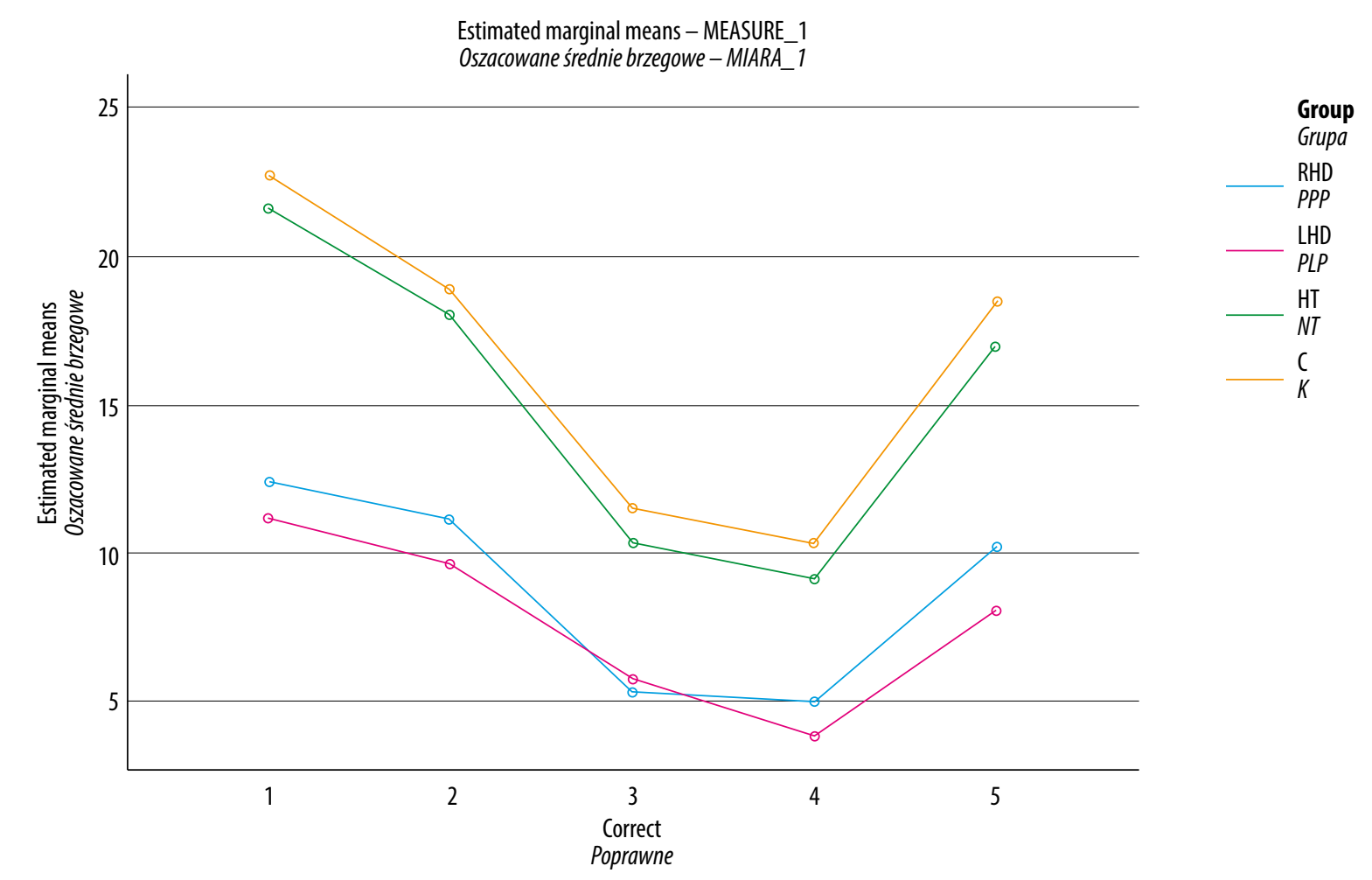

C - controls; HT - hypertension group; LHD - left hemisphere damage; RHD - right hemisphere damage; $\mathbf{1}$ - Animals; $\mathbf{2}$ - verbs; $\mathbf{3}$ - Joy; 4 - Fear; 5 - phonemic fluency. $\boldsymbol{K}$ - grupa kontrolna; $\boldsymbol{N T}$ - grupa z nadciśnieniem tętniczym; PLP - grupa z patologiq lewej półkuli; PPP - grupa z patologia prawej półkuli; 1 - Zwierzęta, 2 - czasowniki, 3 - Radość, 4 - Strach, 5 - fluencja fonemiczna.

Fig. 1. 5 fluency tasks (correct) $\times$ group

Ryc. 1. Poprawne wykonania 5 zadań fluencji $\times$ grupa

HT group $(p=1.0)$. Participants in the HT group performed better than those with RHD and LHD $(p=0.001)$. The main effect of the task variable was also found to be significant, with $61 \%$ impact on the correct performance of fluency tasks. The Animal task $(M=17.00)$ was the best performed task, followed by VF $(M=14.44)$, PF $(M=13.46)$, Joy $(M=8.23)$ and Fear $(M=7.07)$. SF Animals task was performed significantly better than the other tasks $(p=0.001)$, while VF and PF were performed at a similar level $(p=0.38)$. The participants produced more words in the Joy category than in the Fear category $(p=0.031)$, and the performance of each of these tasks was significantly different $(p=0.001)$ from other tasks. The group $\times$ task interaction was also significant, explaining $10 \%$ of the variance in the results (Fig. 1). Healthy subjects were characterised by a better performance of SF than PF $(p=0.001)$ and $\operatorname{VF}(p=0.001)$, while no difference was found between PF and VF results ( $p=1.0)$; emotional tasks were performed at a similar level $(p=0.18)$. In the HT group, the profile was similar to that in the C group: $\mathrm{SF}>\operatorname{VF}(p=0.001)$; $\mathrm{VF}=\mathrm{PF}(p=1.0)$; SF $>$ PF $(p=0.001)$; Joy $=$ Fear $(p=0.78)$. The numbers of correct responses in the RHD group were similar regardless of the type of task: SF $=\mathrm{VF}(p=0.98)$, $\mathrm{SF}=\mathrm{PF}(p=0.08), \mathrm{VF}=\mathrm{PF}(p=1.00)$, Joy $=$ Fear $(p=1.0)$. Subjects with LHD generated a similar number of words in SF and VF $(p=1.0)$, SF and PF $(p=0.08), \mathrm{PF}$ and VF $(p=1.0)$, as well as in emotional categories $(p=0.62)$. poradni neuropsychologicznej. Osoby po udarach były badane w przeddzień wypisu ze szpitala. Dane uczestników zestawiono w tab. 1.

W grupie z PLP znalazło się 15 pacjentów o różnej lokalizacji patologii, w grupie z PPP - 30 chorych, także z różną lokalizacją udaru. Grupa K liczyła 36 osób, a z NT - 33. Grupy nie różniły się istotnie pod względem wieku $(F=2,09$, $p=0,11)$.

Właściwa część badań wymagała realizacji 5 zadań fluencji słownej. SF wymagała wymieniania nazw zwierząt, PF - generowania słów rozpoczynających się fonemem „k”, w VF badany był zaś proszony o wymienienie słów (czasowników): co człowiek robi? Przed wykonaniem każdego zadania uczestnik był instruowany, by nie odmieniał słów (formy odmienione były zaliczane do błędów). Poza zadaniem Zwierzęta akceptowane były nazwy własne. W zadaniach emocjonalnych (EVF) zadanie polegało na wymienianiu słów przychodzących do głowy na hasło Radość, a następnie Strach. Akceptowane były pojedyncze słowa (czasowniki, rzeczowniki, przymiotniki, nazwy własne), a nie zdania. Za każdym razem badany był proszony, by starał się wymienić jak najwięcej słów. Limit wykonania każdego z zadań wynosił 1 minutę. Wskaźnikami wykonania były liczba poprawnych, tj. zgodnych z kryterium, słów oraz liczba błędnych odpowiedzi w postaci powtórzeń, słów niepowiązanych $\mathrm{z}$ kategorią, odmienianych lub zdań. 
Estimated marginal means - MEASURE_1

Oszacowane średnie brzegowe - MIARA_1

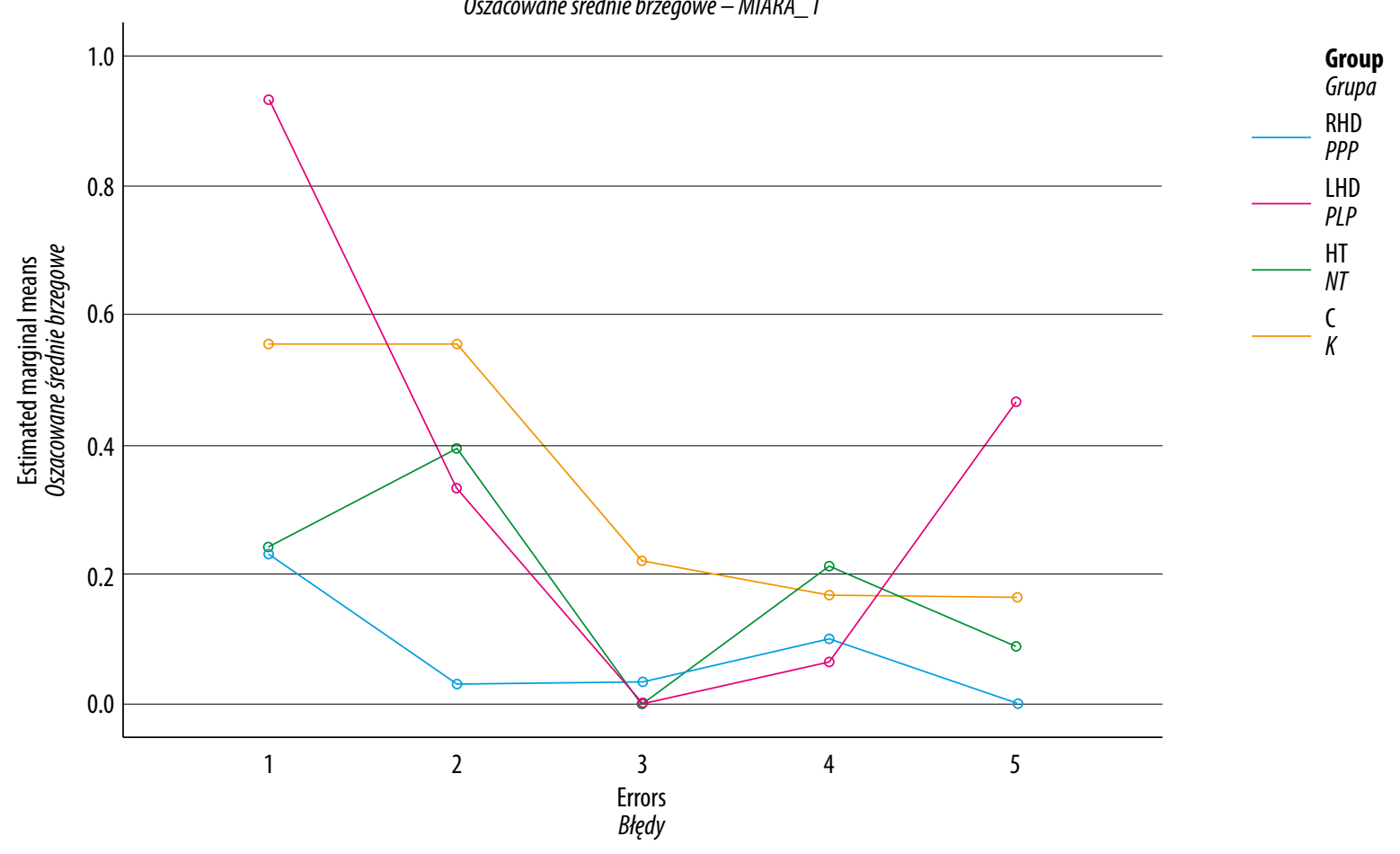

C - controls; HT - hypertension group; LHD - left hemisphere damage; RHD - right hemisphere damage; $\mathbf{1}$ - Animals; $\mathbf{2}$ - verbs; $\mathbf{3}$ - Joy; $\mathbf{4}$ - Fear; $\mathbf{5}$ - phonemic fluency. $\boldsymbol{K}$ - grupa kontrolna; NT - grupa z nadciśnieniem tętniczym; PLP - grupa z patologią lewej półkuli; PPP - grupa z patologia prawej półkuli; 1 - Zwierzęta, 2 - czasowniki, 3 - Radość, 4 - Strach, 5 - fluencja fonemiczna.

Fig. 2. 5 fluency tasks (errors) $\times$ group

Ryc. 2. Błędy w wykonaniu 5 zadań $\times$ grupa

As for the number of errors, their variance was significantly influenced by the task variable. The highest mean of errors in all subjects in total was found for the SF task $(M=0.49)$, insignificantly lower for VF $(M=0.32, p=0.72)$ and, compared to SF, significantly less errors appeared in PF $(M=0.18, p=0.002)$, the Fear task $(M=0.14, p=0.001)$, and the lowest number of errors appeared in the Joy task $(M=0.06, p=0.001)$. There was no difference in the number of errors between VF, PF, and Fear, or the two types of EVF. The main effect of the group variable was also significant. The largest number of errors in all tasks were made by subjects with LHD and controls $(p=1.0)$, while the least in the RHD group. Nevertheless, the incorrect performance profiles were different in each group (Fig. 2). There were no significant differences in the number of errors in the RHD group, regardless of the type of task (post-hoc comparisons $p=1.0)$. In the LHD group, the largest number of errors were made in the SF and PF tasks $(p=0.27)$, followed by $\mathrm{VF}$, whereas the least number of errors were made in emotional tasks $(p=1.0)$, particularly in the positive category. In the $\mathrm{C}$ group, the highest, yet similar, number of errors, occurred in SF and VF tasks ( $p=1.0)$, and the lowest, yet also similar, number of errors occurred in the Fear and PF tasks $(p=1.0)$. In the HT group, the most errors were made in VF, in Animal and Fear categories (post-hoc $p=1.0$ ),

\section{WYNIKI}

W tab. 2 zamieszczono wyniki uczestników. Ryc. 1 ilustruje profile poprawnych wykonań, ryc. 2 - błędnych. Tab. 3 zawiera wyniki dwóch ogólnych modelów liniowych dla pomiarów powtarzalnych. Wykonano analizę dla 4 grup $\times$ 5 zadań fluencji (odpowiedzi poprawne) z uwzględnieniem efektów głównych i interakcji oraz analizę dla odpowiedzi błędnych. Wykorzystano program IBM SPSS v. 26.

W odniesieniu do liczby poprawnych odpowiedzi odnotowano istotny efekt główny zmiennej grupa. Przynależność do grupy w 40\% kształtowała poprawną realizację zadań. Najniższe i nieróżniące się istotnie średnie liczby wszystkich poprawnych odpowiedzi uzyskały grupy z PLP i PPP $(p=1,0)$. Osoby zdrowe otrzymały najlepszy średni wynik, różniąc się pod tym względem istotnie od grup z PPP $(p=0,001)$ i PLP $(p=0,001)$, nie różniąc się natomiast od grupy z NT $(p=1,0)$. Osoby z grupy NT wykonały zadania lepiej w porównaniu z osobami z PPP i PLP $(p=0,001)$. Istotny okazał się także efekt główny zmiennej zadanie, który w $61 \%$ kształtował poprawne wykonanie zadań fluencji. Najlepiej wykonane przez wszystkich badanych zostało zadanie Zwierzęta $(M=17,00)$, kolejno VF $(M=14,44)$, PF $(M=13,46)$, Radość $(M=8,23)$ i Strach $(M=7,07)$. Wykonanie SF Zwierzęta było istotnie lepsze niż pozostałych zadań ( $p=0,001)$, z kolei VF i PF zrealizowano na 


\section{DISCUSSION}

Based on the literature data, we assumed inter- and intragroup differences in verbal fluency task scores between healthy individuals, subjects with HT and those with hemispheric brain damage.

Generally, it was shown that the differences in the profiles of correct answers were quantitative in nature: LHD and RHD groups scored lower, whereas healthy individuals and HT patients scored higher. However, there were differences in error profiles. Subjects with RHD produced the smallest number of errors, with no differences in subsequent tasks, with a small number of correct responses. There were no significantly more intrusions or perseverations described as typical for this pathology lateralisation (Stuss et al., 1998). People with LH stroke produced significantly more errors and scored lower in terms of correct answers compared to other groups, although patients with aphasia were excluded from this group; in turn, healthy individuals, who generated a similar number of mistakes, had significantly better scores in terms of correct answers. Patients with LHD produced the highest number of mistakes in multi-item categories, i.e. Animals and phonemic. On the other hand, healthy individuals produced the highest number of mistakes in the Animals task and the lowest number of mistakes in the phonemic task, similar to those with LHD. Recalling concepts from large categories seems relatively easy due to the well-established network of words they encompass. However, it engages significant working memory resources, which promotes errors, which are also common in those without brain pathologies (Ramage et al., 1999). On the other hand, LHD patients produced fewer mistakes in narrower categories, such as emotional, or semantic categories including less items (Clothing, Vehicles) as these tasks require non-automatically generated responses, which in turn reduces the number of incorrect answers (Pakhomov et al., 2018).

Although the patients achieved similarly low scores in terms of correct task performance regardless of the brain damage lateralisation, there may be different mechanisms of deficits. The difficulties in subjects with LHD may result from impaired phonological and lexical processes (Vigneau et al., 2006), including access to the semantic features of words (Reilly et al., 2015). Stuss et al. (1998) showed lower scores and a greater number of errors in patients with LHD regardless of its location (frontal/extrafrontal), while Bose et al. (2017) confirmed that patients in this group recall fewer words and create poorer clusters (groups of concepts) compared to healthy individuals. In turn, poor performance of RHD patients may be the result of attention dysfunctions (Zimmermann et al., 2014) or, more broadly, impaired executive processes, which are not limited to verbal information (Vigneau et al., 2006). It should be noted that recalling words involves both hemispheres (Gainotti, 2014; Riès et al., 2016; Vigneau et al., 2006, 2011), which accounts for the similar performance in both groups of patients.

Compared to the poorly differentiated correct responses, irrespective of the type of task, in patients after stroke, RHD

\begin{tabular}{|l|c|c|c|}
\hline $\begin{array}{l}\text { Effects } \\
\text { Efekty }\end{array}$ & $\boldsymbol{F}$ & $\boldsymbol{p}$ & $\mathbf{\eta}_{\mathbf{p}}{ }^{2}$ \\
\hline $\begin{array}{l}\text { Task (correct answers) } \\
\text { Zadanie (odpowiedzi poprawne) }\end{array}$ & 173.65 & 0.001 & 0.61 \\
\hline $\begin{array}{l}\text { Task (correct answers) × group } \\
\text { Zadanie (odpowiedzi poprawne) } \times \text { grupa }\end{array}$ & 4.14 & 0.001 & 0.10 \\
\hline $\begin{array}{l}\text { Group } \\
\text { Grupa }\end{array}$ & 24.41 & 0.001 & 0.40 \\
\hline $\begin{array}{l}\text { Task (errors) } \\
\text { Zadanie (błędy) }\end{array}$ & 11.47 & 0.001 & 0.09 \\
\hline $\begin{array}{l}\text { Task (errors) } \times \text { group } \\
\text { Zadanie (błędy) } \times \text { grupa }\end{array}$ & 2.64 & 0.007 & 0.07 \\
\hline $\begin{array}{l}\text { Group } \\
\text { Grupa }\end{array}$ & 3.13 & 0.029 & 0.08 \\
\hline $\begin{array}{l}\boldsymbol{\eta}_{\mathbf{p}}{ }^{2}-\text { partial eta squared. } \\
\boldsymbol{\eta}_{\mathbf{p}}{ }^{-} \text {cząstkowe eta kwadrat. }\end{array}$ & & & \\
\hline
\end{tabular}

Tab. 3. General Linear Model (GLM) for repeated measures: correct vs. incorrect responses

Tab. 3. Ogólny model liniowy dla pomiarów powtarzalnych (General Linear Model, GLM): odpowiedzi poprawne i błędne

podobnym poziomie ( $p=0,38)$. W kategorii Radość badani wymienili więcej słów niż w kategorii Strach $(p=0,031)$, a wykonanie każdego $\mathrm{z}$ tych zadań było na poziomie istotnie różnym $(p=0,001)$ od pozostałych. Istotna była także interakcja grupa $\times$ zadanie, która wyjaśniała $10 \%$ wariancji wyników (ryc. 1). Dla zdrowych badanych charakterystyczne było lepsze wykonanie SF niż PF $(p=0,001)$ i niż VF $(p=0,001)$, a rezultaty PF i VF się nie różniły $(p=1,0)$; zadania emocjonalne zostały wykonane podobnie $(p=0,18)$. $\mathrm{W}$ grupie z NT profil był zbliżony jak w grupie K: SF $>$ VF $(p=0,001) ; \mathrm{VF}=\mathrm{PF}(p=1,0) ; \mathrm{SF}>\mathrm{PF}(p=0,001) ;$ Radość $=\operatorname{Strach}(p=0,78)$. Liczby poprawnych odpowiedzi w grupie PPP były podobne niezależnie od typu zadania: $\mathrm{SF}=\mathrm{VF}$ $(p=0,98), \mathrm{SF}=\mathrm{PF}(p=0,08), \mathrm{VF}=\mathrm{PF}(p=1,00)$, Radość $=$ Strach $(p=1,0)$. Osoby z PLP podały zbliżoną liczbę słów w SF i VF $(p=1,0)$, w SF i PF $(p=0,08)$ oraz w PF i VF $(p=1,0)$, a także w kategoriach emocjonalnych $(p=0,62)$. W odniesieniu do liczby błędów ich wariancję kształtowało istotnie zadanie. Najwyższa średnia błędów u wszystkich badanych łącznie została odnotowana w zadaniu SF $(M=0,49)$, nieistotnie mniejsza w VF $(M=0,32, p=0,72)$, następnie $\mathrm{w}$ porównaniu $\mathrm{z}$ SF istotnie mniej błędów pojawiło się w PF $(M=0,18, p=0,002)$, w zadaniu Strach $(M=0,14, p=0,001)$ i najmniej w zadaniu Radość $(M=0,06$, $p=0,001)$. Liczba błędów nie różnicowała VF, PF i Strachu ani obu typów EVF. Istotny był również efekt główny zmiennej grupa. Najwięcej błędów we wszystkich zadaniach popełniły grupy z PLP i K $(p=1,0)$, najmniej - z PPP. Mimo to profile błędnych wykonań były inne w każdej grupie (ryc. 2). W grupie z PPP nie odnotowano istotnych różnic w zakresie liczby błędów niezależnie od typu zadania (porównania post-hoc $p=1,0$ ). W grupie $\mathrm{z}$ PLP najwięcej błędów dotyczyło SF i PF ( $p=0,27)$, następnie VF, a najmniej - zadań emocjonalnych $(p=1,0)$, szczególnie w kategorii pozytywnej. W grupie K najwyższa, ale zbliżona liczba błędów dotyczyła SF i VF $(p=1,0)$, a najniższa i również 
and LHD, the profiles of correct performance in healthy and HT individuals show some differences depending on the type of task (SF > VF and SF > PF). The same pattern of correct responses from healthy subjects has been reported in other reports (Ardila et al., 2006; Tallberg et al., 2008). Generally, the numbers of correct answers in subjects with HT did not differ significantly from those in healthy subjects, although they were lower. This is consistent with other studies that indicate that controlled hypertension may not differentiate the performance of patients and healthy individuals (Morelli et al., 2017); however, verbal fluency may be a useful tool to monitor cognitive functions (Jimenéz et al., 2018). At this point, attention should be paid to the error profile, different from that in other groups: verb fluency and the Fear category were found to be the most difficult for HT patients. Both of these tasks strongly involve executive functions, the impairment of which is one of the more distinct features of cognitive deficits in HT (Moraes et al., 2019).

Emotional tasks with different valences (Joy, Fear) were performed at a similar level in all groups. Compared to other tasks, the respondents achieved the lowest scores in this case, regardless of their group, which is consistent with the fact that these tasks are difficult due to the requirements and the involvement of multiple functions: semantic, executive, and autobiographical memory. Despite a large body of evidence showing asymmetry in the modulation of emotions and verbal emotional memory, our results did showed no dissociation in the correct performance of the positively and negatively charged EVF tasks in individuals after RH and LH stroke. Other studies showed no significant differences in healthy individuals (Gawda et al., 2017), while dissociation among patients with CNS vascular pathology was observed after using broader emotional categories (pleasant unpleasant): individuals with RHD produced more words in the positive rather than negative category as opposed to patients with LHD (Szepietowska and Lipian, 2012). However, only healthy individuals produced fewer errors in the negative category than in the positive one, and the remaining groups showed a different error pattern.

To conclude, patients with vascular hemispheric pathology and those at risk achieved lower scores in all types of fluency tasks compared to healthy individuals, which is in line with many other reports. This means that this method may be useful in differentiating between healthy individuals and those with CNS damage, as well as in the monitoring of the cognitive status in patients with vascular diseases. Despite the large body of evidence emphasizing the presence of verbal fluency profiles specific for lateralised brain pathology, this was not confirmed by our data. Future studies should involve a detailed analysis of the types of errors produced by patients with hemispheric pathology in different types of verbal fluency tasks. Possible explanations for the results include a failure to consider pathology location (anterior/posterior region of each hemisphere), which can significantly shape performance patterns (Stuss et al., 1998), and a relatively small sample size. zbliżona wystąpiła w zadaniach Strach i PF $(p=1,0)$. W grupie z NT najwięcej błędów popełniono $\mathrm{w}$ VF, $\mathrm{w}$ kategoriach Zwierzęta i Strach (post-hoc $p=1,0$ ), więcej niż w kategoriach Radość i PF.

\section{OMÓWIENIE}

Na podstawie danych z piśmiennictwa zakładano międzygrupowe i wewnątrzgrupowe zróżnicowanie wyników w testach fluencji słownej u osób zdrowych, z NT oraz naczyniowym uszkodzeniem półkul mózgu.

Najogólniej wykazano, że różnice w profilach poprawnych odpowiedzi miały charakter ilościowy: niższe wyniki dotyczyły grup z PLP i PPP, wyższe zaś - osób zdrowych i z NT. Z kolei profile błędów były odmienne. Najmniejsza liczba błędów, niezróżnicowana w kolejnych zadaniach, przy jednocześnie niewielkiej liczbie poprawnych reakcji cechowała osoby z PPP. Nie odnotowano istotnie większej liczby wtrąceń czy perseweracji opisywanych jako typowe przy takiej lateralizacji patologii (Stuss et al., 1998). Osoby po udarze LP, mimo że wykluczono spośród nich te $\mathrm{z}$ afazją, popełniły istotnie więcej błędów, uzyskując także niższe wyniki w zakresie poprawnych odpowiedzi w porównaniu $\mathrm{z}$ innymi grupami; $\mathrm{z}$ kolei osoby zdrowe, popełniając równie dużo błędów, uzyskały znacząco lepsze wyniki w zakresie poprawnych odpowiedzi. Pacjenci z PLP popełnili najwięcej błędów $w$ kategoriach zawierających wiele egzemplarzy, tj. Zwierzęta i fonemiczna. Osoby zdrowe z kolei, podobnie jak z PLP, najwięcej błędów popełniły w zadaniu Zwierzęta, ale najmniej w kategorii fonemicznej. Przypominanie sobie pojęć $z$ dużych kategorii wydaje się stosunkowo łatwe ze względu na dobrze utrwaloną sieć zaliczanych do nich słów. Angażuje jednak znaczące zasoby pamięci operacyjnej, co sprzyja błędom, które są częstym zjawiskiem także u osób bez patologii mózgu (Ramage et al., 1999). Z kolei w kategoriach węższych, jak choćby emocjonalne czy mniej liczne kategorie semantyczne (Odzież, Pojazdy), pacjenci z PLP popełnili mniej błędów, gdyż zadania te wymagają niezautomatyzowanego generowania słów, co ogranicza liczbę niewłaściwych odpowiedzi (Pakhomov et al., 2018).

Chociaż niezależnie od lateralizacji uszkodzenia pacjenci uzyskali podobnie niskie wyniki w zakresie poprawnych wykonań testów, to mechanizmy deficytów mogą być odmienne. Trudności osób z PLP mogą wynikać z osłabienia procesów fonologiczno-leksykalnych (Vigneau et al., 2006), w tym dostępu do semantycznych cech słowa (Reilly et al., 2015). Stuss i wsp. (1998) wykazali niższe wyniki i większą liczbę błędów w grupach z PLP niezależnie od lokalizacji patologii (czołowa - pozaczołowa), a Bose i wsp. (2017) potwierdzili, że pacjenci z tej grupy przypominają sobie mniej słów i tworzą uboższe klastery (grupy pojęć) w porównaniu ze zdrowymi. $Z$ kolei niskie wyniki pacjentów z PPP mogą być skutkiem zakłóceń procesów uwagowych (Zimmermann et al., 2014) czy szerzej - wykonawczych, nieograniczających się jedynie do informacji werbalnej (Vigneau et al., 2006). Należy uwzględnić fakt, że przypominanie słów angażuje obie półkule (Gainotti, 2014; Riès et al., 2016; 
test performance should be also mentioned. Despite these shortcomings, this is the first, to our knowledge, Polish study on clinical groups assessed for various types of verbal fluency.

\section{Conflict of interest}

The authors do not report any financial or personal connections with other persons or organisations, which might negatively affect the contents of this publication and/or claim authorship rights to this publication.

\section{References / Piśmiennictwo}

Abbassi E, Kahlaoui K, Wilson MA et al.: Processing the emotions in words: The complementary contributions of the left and right hemispheres. Cogn Affect Behav Neurosci 2011; 11:372-385.

Abeare CA, Freund S, Kaploun K et al.: The Emotion Word Fluency Test (EWFT): initial psychometric, validation, and physiological evidence in young adults. J Clin Exp Neuropsychol 2017; 39: 738-752.

Ardila A, Ostrosky-Solís F, Bernal B: Cognitive testing toward the future: the example of Semantic Verbal Fluency (ANIMALS). Int J Psychol 2006; 41: 324-332.

Babulal GM: Associations between stroke lesion location and verbal fluency tests in a sub-acute stroke population. Neurol Disord Therap 2016; 1. DOI:10.15761/NDT.1000101.

Beraha E, Eggers J, Hindi Attar C et al.: Hemispheric asymmetry for affective stimulus processing in healthy subjects - a fMRI study. PLoS One 2012; 7: e46931.

Biesbroek JM, van Zandvoort MJE, Kappelle LJ et al.: Shared and distinct anatomical correlates of semantic and phonemic fluency revealed by lesion-symptom mapping in patients with ischemic stroke. Brain Struct Funct 2016; 221: 2123-2134.

Birn RM, Kenworthy L, Case L et al.: Neural systems supporting lexical search guided by letter and semantic category cues: a self-paced overt response fMRI study of verbal fluency. Neuroimage 2010; 49: 1099-1107.

Bitniok M: Przesiewowy Test Badania Afazji Frenchay (FAST) - polska wersja. Typescript made available by the author for clinical use, 1998 .

Bloom RL, Borod JC, Obler LK et al.: A preliminary characterization of lexical emotional expression in right and left brain-damaged patients. Int J Neurosci 1990; 55: 71-80.

Borod JC, Andelman F, Obler LK et al.: Right hemisphere specialization for the identification of emotional words and sentences: evidence from stroke patients. Neuropsychologia 1992; 30: 827-844.

Borod JC, Cicero BA, Obler LK et al.: Right hemisphere emotional perception: evidence across multiple channels. Neuropsychology 1998; 12: 446-458.

Bose A, Wood R, Kiran S: Semantic fluency in aphasia: clustering and switching in the course of 1 minute. Int J Lang Commun Disord 2017; 52: 334-345.

Buchanan TW: Retrieval of emotional memories. Psychol Bull 2007; 133: 761-779.

Cabeza R, St Jacques P: Functional neuroimaging of autobiographical memory. Trends Cogn Sci 2007; 11: 219-227.

Cohen M, Shaver P: Avoidant attachment and hemispheric lateralisation of the processing of attachment- and emotion-related words. Cogn Emot 2004; 18: 799-813.

Gainotti G: Why are the right and left hemisphere conceptual representations different? Behav Neurol 2014; 2014: 603134.

Gawda B, Szepietowska E, Soluch P et al.: Valence of affective verbal fluency: fMRI studies on neural organization of emotional concepts Joy and Fear. J Psycholinguist Res 2017; 46: 731-746.

Goldberg E, Costa LD: Hemisphere differences in the acquisition and use of descriptive systems. Brain Lang 1981; 14: 144-173.

Homskaya ED, Batowa NJ: Мозг и эмоции. Нейропсихологическое исследование [Mózg i emocje: badanie neuropsychologiczne]. Российское педагогическое агентство, Москва 1992.
Vigneau et al., 2006, 2011), co wyjaśnia podobieństwo wykonań w obu grupach pacjentów.

W porównaniu z mało zróżnicowanymi poprawnymi realizacjami niezależnie od typu zadania u osób po udarze PP i LP profile poprawnych realizacji u osób zdrowych i z NT cechuje pewne zróżnicowanie zależne od typu zadania (SF > VF i SF > PF). Taki sam wzorzec poprawnych odpowiedzi zdrowych badanych opisywano w innych doniesieniach (Ardila et al., 2006; Tallberg et al., 2008). Zasadniczo liczby poprawnych odpowiedzi osób z NT nie różniły się istotnie od wyników osób zdrowych, chociaż były niższe. Jest to zgodne z rezultatami innych badań, które wskazują, że kontrolowane NT może nie różnicować wyników chorych i osób zdrowych (Morelli et al., 2017), ale fluencja słowna może być narzędziem przydatnym w monitorowaniu kondycji poznawczej (Jimenéz et al., 2018). Tu na uwagę zasługuje profil błędów, inny od występujących w pozostałych grupach: dla osób z NT najtrudniejsze okazały się fluencja czasownikowa i kategoria Strach. Oba te zadania w znaczącym stopniu angażują funkcje wykonawcze, których zakłócenia stanowią jedną z wyraźniejszych cech deficytów poznawczych w NT (Moraes et al., 2019).

Zadania emocjonalne o odmiennej walencji (Radość, Strach) zostały wykonane na podobnym poziomie przez wszystkie grupy. $\mathrm{W}$ porównaniu $\mathrm{z}$ innymi zadaniami badani, niezależnie od przynależności do grupy, uzyskali w tym wypadku najniższe wyniki, co jest zgodne $\mathrm{z}$ faktem, że zadania te są trudne ze względu na wymagania i udział wielu funkcji: semantycznych, wykonawczych, pamięci autobiograficznej. Pomimo wielu danych wskazujących na asymetrię w regulacji emocji i werbalnej pamięci emocjonalnej wyniki autorek nie wykazały dysocjacji w poprawnych wykonaniach kategorii pozytywnej i negatywnej EVF u osób po udarze PP i LP. Inne badania wykazały brak istotnych różnic u zdrowych osób (Gawda et al., 2017), natomiast dysocjację wśród osób z naczyniową patologią OUN odnotowano po zastosowaniu szerszych kategorii emocjonalnych (przyjemne nieprzyjemne): osoby z PPP wymieniały więcej słów w kategorii pozytywnej niż negatywnej, a u osób z PLP uzyskano odwrotny wzorzec wykonania (Szepietowska i Lipian, 2012). Jednak tylko osoby zdrowe popełniły mniej błędów w kategorii negatywnej niż w pozytywnej, a pozostałe grupy cechowały się odmiennym wzorcem, jeśli chodzi o błędy.

Podsumowując, należy stwierdzić, że zgodnie $\mathrm{z}$ wieloma innymi doniesieniami w porównaniu ze zdrowymi badanymi osoby z naczyniową patologią półkul, a także te $\mathrm{z}$ grupy ryzyka uzyskały niższe wyniki we wszystkich typach fluencji. Oznacza to, że metoda ta może być przydatna w różnicowaniu osób zdrowych i z uszkodzeniem OUN oraz w monitorowaniu stanu poznawczego pacjentów $\mathrm{z}$ obciążeniem naczyniowym. Mimo wielu danych podkreślających obecność specyficznych dla zlateralizowanej patologii mózgu profili fluencji słownej dane uzyskane przez autorki tego nie wykazały. W kolejnych badaniach uwagę należałoby poświęcić szczegółowej analizie typów błędów popełnianych przez osoby z patologią półkul w różnych typach zadań fluencji 
Jimenéz XO, Rivera FG, Muñoz BS: Cognitive components of verbal fluency in non-demented older adults with cerebrovascular risk factors. A two-year follow-up. Revista Iberoamericana de Neuropsicología 2018; 1: 163-169.

Jodzio K: Neuropoznawcze korelaty spadku fluencji słownej po udarze prawej półkuli mózgu. Stud Psychol 2006; 44: 5-18.

Kahlaoui K, Scherer LC, Joanette Y: The right hemisphere's contribution to the processing of semantic relationships between words. Lang Linguist Compass 2008; 2: 550-568.

Klaus J, Hartwigsen G: Dissociating semantic and phonological contributions of the left inferior frontal gyrus to language production. Hum Brain Mapp 2019; 40: 3279-3287.

Knutson KM, Dal Monte O, Schintu S et al.: Areas of brain damage underlying increased reports of behavioral disinhibition. J Neuropsychiatry Clin Neurosci 2015; 27: 193-198.

Lam BPW, Marquardt TP: The Emotional Verbal Fluency Task: a close examination of verbal productivity and lexical-semantic properties. J Speech Lang Hear Res 2020; 63: 2345-2360.

Le Blanc B, Joanette Y: Unconstrained oral naming in left- and righthemisphere-damaged patients: an analysis for naturalistic semantic strategies. Brain Lang 1996; 55: 42-45.

Martin JM, Altarriba J: Effects of valence on hemispheric specialization for emotion word processing. Lang Speech 2017; 60: 597-613.

Molinari M, Leggio M: Chapter 4 - Cerebellum and verbal fluency (phonological and semantic). In: Mariën P, Manto M (eds.): The Linguistic Cerebellum. Academic Press, 2016: 63-80.

Moraes NC, Aprahamian I, Yassuda MS: Executive function in systemic arterial hypertension: a systematic review. Dement Neuropsychol 2019; 13: 284-292.

Morelli NL, Cachioni M, Lopes A et al.: Verbal fluency in elderly with and without hypertension and diabetes from the FIBRA study in Ermelino Matarazzo. Dement Neuropsychol 2017; 11: 413-418.

Paek EJ, Murray LL, Newman SD: Neural correlates of verb fluency performance in cognitively healthy older adults and individuals with dementia: a pilot fMRI Study. Front Aging Neurosci 2020; 12: 73.

Pakhomov SVS, Eberly LE, Knopman DS: Recurrent perseverations on semantic verbal fluency tasks as an early marker of cognitive impairment. J Clin Exp Neuropsychol 2018; 40: 832-840.

Ramage A, Bayles K, Helm-Estabrooks N et al.: Frequency of perseveration in normal subjects. Brain Lang 1999; 66: 329-340.

Ramsberger G: Repetition of emotional and nonemotional words in aphasia. J Med Speech Lang Pathol 1996; 4: 1-12.

Reilly M, Machado N, Blumstein SE: Hemispheric lateralization of semantic feature distinctiveness. Neuropsychologia 2015; 75: 99-108.

Riès SK, Dronkers NF, Knight RT: Choosing words: left hemisphere, right hemisphere, or both? Perspective on the lateralization of word retrieval. Ann N Y Acad Sci 2016; 1369: 111-131.

Roberts P, Le Dorze G: Semantic verbal fluency in aphasia: a quantitative and qualitative study in test-retest conditions. Aphasiology 1994; 8: 569-582.

Salas Riquelme CE, Radovic D, Castro O et al.: Internally and externally generated emotions in people with acquired brain injury: preservation of emotional experience after right hemisphere lesions. Front Psychol 2015; 6: 101

Sanjuán A, Bustamante JC, Forn C et al.: Comparison of two fMRI tasks for the evaluation of the expressive language function. Neuroradiology 2010; 52: 407-415.

Sass K, Fetz K, Oetken S et al.: Emotional verbal fluency: a new task on emotion and executive function interaction. Behav Sci (Basel) 2013; 3: 372-387.

Schmidt CSM, Nitschke K, Bormann T et al.: Dissociating frontal and temporal correlates of phonological and semantic fluency in a large sample of left hemisphere stroke patients. Neuroimage Clin 2019; 23: 101840.

Shao Z, Janse E, Visser K et al.: What do verbal fluency tasks measure? Predictors of verbal fluency performance in older adults. Front Psychol 2014; 5: 772.

Shinagawa S, Babu A, Sturm V et al.: Neural basis of motivational approach and withdrawal behaviors in neurodegenerative disease. Brain Behav 2015; 5: e00350. słownej. Możliwymi wyjaśnieniami wyników są nieuwzględnienie lokalizacji patologii (przedni - tylny obszar każdej z półkul), która może istotnie kształtować wzorce wykonań (Stuss et al., 1998) oraz stosunkowo mała liczebność grup tych pacjentów. Warto również wskazać na brak kontroli innych zmiennych istotnych dla wykonywania testów fluencji. Mimo tych niedociągnięć są to pierwsze, według wiedzy autorek, polskie badania dotyczące grup klinicznych, w których uwzględniono różne typy fluencji słownej.

\section{Konflikt interesów}

Autorki nie zgłaszają żadnych finansowych ani osobistych powiązań z innymi osobami lub organizacjami, które mogłyby negatywnie wpłynać na treść publikacji oraz rościć sobie prawo do tej publikacji.

Sitek EM, Konkel A, Międzobrodzka E et al.: Kliniczne zastosowanie prób fluencji słownej w chorobie Huntingtona. Hygeia Public Health 2014; 49: 215-221.

Stuss DT, Alexander MP, Hamer L et al.: The effects of focal anterior and posterior brain lesions on verbal fluency. J Int Neuropsychol Soc 1998; 4: 265-278.

Sutton SK, Davidson RJ: Prefrontal brain asymmetry: a biological substrate of the behavioral approach and inhibition systems. Psychol Sci 1997; 8: 204-210.

Szepietowska EM, Gawda B: Fluencja czasownikowa i rzeczownikowa: mechanizmy neuronalne - badania $\mathrm{z}$ zastosowaniem funkcjonalnego rezonansu magnetycznego. Neuropsychiatr Neuropsychol 2014; 9: 81-87.

Szepietowska EM, Lipian J: Fluencja słowna neutralna i afektywna u chorych $\mathrm{z}$ uszkodzeniem prawej, lewej lub obu półkul mózgu. Psychiatr Pol 2012; 46: 539-551.

Tallberg IM, Ivachova E, Jones Tinghag K et al.: Swedish norms for word fluency tests: FAS, animals and verbs. Scand J Psychol 2008; 49: 479-485.

Troyer AK, Moscovitch M: Cognitive processes of verbal fluency tasks. In: Poreh AM (ed.): Studies on Neuropsychology, Neurology and Cognition. The Quantified Process Approach to Neuropsychological Assessment. Taylor \& Francis, 2006: 143-160.

Vigneau M, Beaucousin V, Hervé PY et al.: Meta-analyzing left hemisphere language areas: Phonology, semantics, and sentence processing. Neuroimage 2006; 30: 1414-1432.

Vigneau M, Beaucousin V, Hervé PY et al.: What is right-hemisphere contribution to phonological, lexico-semantic, and sentence processing? Insights from a meta-analysis. Neuroimage 2011; 54: 577-593.

Wagner S, Sebastian A, Lieb K et al.: A coordinate-based ALE functional MRI meta-analysis of brain activation during verbal fluency tasks in healthy control subjects. BMC Neurosci 2014; 15: 19.

Wauters L, Marquardt TP: Category, letter, and emotional verbal fluency in Spanish-English bilingual speakers: a preliminary report. Arch Clin Neuropsychol 2018; 33: 444-457.

Whiteside DM, Kealey T, Semla M et al.: Verbal fluency: language or executive function measure? Appl Neuropsychol Adult 2016, 23: 29-34.

Zhao Q, Guo Q, Hong Z: Clustering and switching during a semantic verbal fluency test contribute to differential diagnosis of cognitive impairment. Neurosci Bull 2013; 29: 75-82.

Zimmermann N, Branco L, Ska B et al.: Verbal fluency in right brain damage: dissociations among production criteria and duration. Appl Neuropsychol Adult 2014; 21: 260-268. 